\title{
Index of titles and first lines
}

All references are to poem numbers. Spellings of titles have been modernized. First lines in old spelling, but alphabetized according to equivalent modern spellings. ' $A$ ' and 'The' are retained at the start of the entry, and taken into account in the alphabetical sequence, in first lines but not in titles. Speech-headings in dialogue are omitted.

A Blithe and bonny Country-Lasse 79

A fairest Ganymede, disdaine me not 97

A Jollie sheppard 180

A Paradice on earth is found 165

A Shepheard poore, Eubulus call'd he was 141

A Sheephard who no care did take 210

A Silly poor Sheepherd 264

A Silly Sheepheard lately sate 119

Affectionate Shepherd, The, from 'The

Second Day' 95

Affectionate Shepherd, The, from 'The

Shepherd's Content' 96

Ah trees why fall your leaues so fast? 82

Ah what is loue? is it a pretie thing 75

Ah! when I call to Mind that happy

Time 201

Alas our sheappeard now is strocke againe 181

Alas my hart, mine eye hath wronged thee 89

Alexis if thy worth doe not disdaine 185

'Alexis to Damon' 198

All Gentlemen and Yeomen good 156

$\mathrm{Al}$ hayle Minalcas, nowe by my fayth well met 28

'All Hail to Hatfield' 237

Along the verdant fields all richly dide 35

Although I am a Countrey Lasse 151

Among the rustie rockes, bothe rough and harde by kinde 54

Among thy sheepe ô Lord I seemd to feed 110

'Amor Constans' 204

Amphrisa the Forsaken Shepherdess, extracts 93

Amyntas, The Argument 60

Amyntas, 'Lamentation II' 57

Amyntas, 'Last Lamentation' 58

An Elder time there was so yore 153

And are you there old Pas? in troth I euer thought 49

And now at length this fit shee doeth recouer 92

And now from solid Prose I will abstaine 213

And now since Phillis dead corps was layd in a coffyn 58

And wilt thou then, Alexis mine, depart? 197

'Another of the same nature' 86

'Apollo, Daphne and the Shepherd' 66

Apollo (father of the Sisters nine 213

Arcadia, Old, poem 447

Arcadia, Old, poem 1748

Arcadia, Old, poem 2949

Arcadia, Old, poem 3450

Arcadia, Old, poem 7151

Arcadia, Old, poem 7552

Arcadian Lovers, The 157 
'Arcadian Syrinx' 61

Arcadian Syrinx was a Nymph most noble, amongst all 61

'Argentile and Curan' 56

As att noone Dulcina rested 159

As Colin went forth 265

As I late wandred over a Plaine 269

As vhen a sheaphard boy from fearful hight 200

Asks thou, ith'Country how I spend the Day? 13

Astrcea daughter of the immortall Ioue 65 Astrophel 43

Attend then Shepheards, now I doe begin 206

At the Spring 218

Aurora from old Tithons frosty bed 219

Bad are the times 242

'Beautiful Shepherdess of Arcadia, The' 158

Because thou recountest of thy fidelitie 27

Blest be the man (and blest he is) whom'ere 225

Borrill, why sit'st thou musing in thy coate? 160

Britannia's Pastorals, extracts 189,190

But Flaccus, now more happy he appears 232

But Muse, from her so low, diuert thy highset song 163

But, noble Muse, proceed immediatly to tell 163

But now the second Morning, from her bowre 178

Careless Shepherdess, The, extract 195

Chloris Sonnet 3103

Chloris Sonnet 5104

'Christmas' Part II 222

Christ's Victory and Triumph, extracts 178

Cleere had the day bin from the dawne 166

Cloris, since thou art fled away 263

Close by a River cleare, whose bankes were clad 177

Colin Clout's Come Home Again, extracts 42

Come Espilus, come now declare thy skill 46

Come follow me merily my mates 173

Cumme gentle Heardman sitt with mee 67
Come let vs walke that wee may sweetely heare 240

Come liue with mee, and be my deere 86

Come live with me, and be my love (Cotton) 276

Come liue with mee, and be my loue (Marlowe) 84

Come love, lets walke into the springe 154

Come Marina let's away 207

Come neere and view my pallace how it stands 236

Come Shepherds come, impale your brows 195

Come Shepheards, decke your heads 148

Come shepheards weedes, become your masters minde 47

Come Sons of Summer, by whose toile 244

'Complaint of the Shepherd Harpelus, The' 179

Consolation of Philosophy, The, Bk II Poem 514

Cool Shades, Air-fanning Groves 20

'Coridon and Strephon' 268

Coridon, arise my Coridon 133

'Coridon to his Phillis' 89

'Coridon's Song' 79

'Coridon's Supplication to Phillis' 120

Countries delight, sweet Phillis, Beuties pride 59

'Country Lass, The' 68

'Country Lass, The' 151

'Country life, A' 274

'Country Life, The' 225

Cynthia Sonnet 1597

Cynthia Sonnet 1898

'Damextas' Jig in Praise of His Love' 134

'Damon: Or a Pastoral Elegy', extracts 201

'Damon and Moeris' 196

Damon and Moeris by a christal spring 196

'Damon's Ditty' 100

'Daphnis: An Elegiac Eclogue' 252

Day which so bright didst shyne, how darck art thow? 102

Dearest in Friendship, if you'll know 247

Dear leave thy home and come with me 216

Deer! on yond' Mountain stands my humble Cot 171 
Dear Silvia let thy Thirsis know 260

Deare Thyrsis! tell thy Corydon 250

Descensus Astraeae, extracts 65

'Description of Arcadia' 106

'Description of Shepherds and Shepherdesses, A' 256

'Description of the Shepherd and His Wife' 74

'Dialogue between Two Shepherds in Praise of Astraea' 139

'Dialogue betwixt A Nymph and A Shepherd, A' 229

'Dialogue betwixt Lucasia and Rosania, A' 273

'Dialogue Weeping the Loss of Pan, A' 246

Doe I mistake? or from Elyzium cleare 231

DoRILvs in sorrowes deepe 164

'Doron's Eclogue Joined with Carmela's' 73

'Doron's Jig' 72

Eclogue I (Barclay), extract 26

Eclogue I (Basse) 169

Eclogue I (Cokayn) 268

Eclogue I (Virgil) 6

Eclogue I.1-8 (Virgil) 4

Eclogue II (Googe) 32

Eclogue II (Virgil) 7

Eclogue III (Barclay), extract 27

Eclogue IV (Barclay), extracts 28

Eclogue IV (Mantuan), extract 15

Eclogue IV (Virgil) 8

Eclogue VI (Mantuan), extract 16

Eclogue VII (Mantuan), extract 17

Eclogue IX, 1606 (Drayton) 162

Eclogue X (Virgil) 9

'Eclogue between a Carter and a Shepherd, An' 215

'Eclogue between a Shepherd and a Herdman, An' 67

'Eclogue between Willy and Wernocke, An' 184

'Eclogue: Corydon, Clotten' 275

'Eclogue Gratulatory to Robert Earl of Essex, An' 64

'Eclogue Occasioned by Two Doctors Disputing upon Predestination, An' 227

'Eclogue on the Palilia on Cotswold Hills, An' 228

'Eclogue to Master Jonson' 226
'Eclogue upon the Death of Sir Philip Sidney' 138

Eclogues, Prologue (Barclay) 25

Elegy III (Basse), extract 168

'Epitaph on Bion' 5

'Epitaph on Robert Cecil' 143

Epode II (Horace) 12

Epode III (Casimir) 232

'Erycine at the Departure of Alexis' 197

'Excellent Pastoral Ditty, An' 128

Faerie Queene, The, extracts 44, 45

Fair Dulcina Complaineth 149

Fair golden Age! when milk was th' onely food 34

Faire in a morne, (ô fairest morne) 114

Faire Phillis is the Sheepheards Queene 115

Fair Shepardes why dost thou weep 246

Fair sheperdess that feedest thy fair flocks 130

Faire siluer-footed Thetis that time threw 190

Fair Virtue, extract 186

'Farewell to the World, A' 122

Feede on my Flocks securely 144

Feede silly sheepe although your keeper pineth 103

'Fiction How Cupid Made a Nymph Wound Herself with His Arrows' 140

Fie on the sleights that men deuise 145

Fields were ouer-spred with floures 106

'For a Sheep-shearing' 187

'For a Shepherd' 188

For shame man will thou never leave thy sorrow 204

Forsooth frende Cornix nought can my heart make light 26

Fragment of a Greater Work 200

From England, Scotland, Wales and Ireland 261

From Fortunes frownes and change remou'd 78

From the Ramme 182

Fuimus Troes, songs 218

Gentlemen, Gentlemen, listen to my Ditty 259

Georgic II (Virgil), extract 10

Georgic III (Virgil), extract 11 
God speede my freend, why sittst thou heere so sadd? 129

Golden Age Chorus (Guarini) 34

Golden Age Chorus (Tasso) 33

Good day, Mirtillo 241

'Good Shepherd's Sorrow, The' 147

Great Pan the Father of our peace, and pleasure 193

Gvarda mi las vaccas 24

Hail happy day! Dorus, sit down 271

Happy is He, that free from Mental Toil 12

Happy to muche the formar Age 14

'Harpelus' Complaint' 31

He suffers in warme Cottages 11

Hence forth I will nott sett my loue 68

Herdgrome, what gars thy pipe to goe so loud? 64

'Herdman's Happy Life, The' 69

Heere Hobbinoll lyes, our shepeheard whilere 143

'Hermes and Lycaon' 202

Hey troly loly lo mayde, whether go you? 30

Himatia-Poleos, Song from 182

'Hock-Cart, The' 244

Ho jolly Thirsis whither in such hast? 227

How blest art thou, canst loue the countrey, WROTH 192

How now shepheard what meanes that 205

How Sacred and how Innocent 274

'[Hymn] For a Sheep-shearing' 187

'[Hymn] For a Shepherd' 188

'Hymn to Pan' 175

I Hate the Countries dust and manners, yet 223

I have lost my melch cow 240

I pray thee, keepe my kine for mee 24

I sing diuine ASTREAS praise 139

Idea the Shepherd's Garland VII 160

Idea the Shepherd's Garland VIII 161

Idyll I.4-6 (Theocritus) 4

Idyll VIII (Theocritus) 1

Idyll XI (Theocritus) 2

If all the world and love were young 85

If he shall choose the horned Scire 4

If plaints could penetrate the sun-bright top of Olympus 105

If thou wilt loue me, thou shalt be my Boy 95
If yet, if yet 193

In a field full fayer of flowers 107

In peticot of Greene 170

'In Praise of a Country Life' 248

In sad and Ashy weeds 147

In seemely sorte I like to love 127

In sweetest prime, and blooming of his Age 199

In the merry moneth of May 117

In this merry Maying time 150

In time of yor when shepperds dwelt 113

'Invitation to Phyllis, An' 276

Iolly shepheard and vpon a hill as he sate 172

Iolly Sheepheard, Sheepheard on a hill 134

Is not that the noblyst thyng in dede 19

Is not thilke same a goteheard prowde 41

'Isle of Man, The' 261

It chaunst of late a Shepheardes swaine 140

It was neere a thickie shade 74

Jack! Nay prithee come away 254

'Jack the Plough-Lad's Lamentation' 259

'Jolly Shepherd, The' 270

Kala old Mopsus wife 21

'Kala's Complaint' 21

Lady of May, The, extract 46

'Lamentation II' (Amyntas) 57

'Land-schap between Two Hills, The' 266

'Last Lamentation' (Amyntas) 58

Late t'was in June the fleece when fully grown 162

'Laurinella, of True and Chaste Love' 169

Libri 4 Plantarum, extract 225

Lo Collin, here the place, whose pleasaunt syte 40

Long hath my sufferance labored to inforce 81

Lost in the mudd of thos hygh flowinge streames 142

Loue as well can make abiding 209

Lover's Delight, The 154

Love's Victory: Song 211

'Lycidas' 230

Mated with greefe a faithfull sheephearde sate 128

'Mercury's Song' 94 
'Milkmaids, The' 267

Moderatus, extract 99

More leane (Oh Ianus) seemes thy Goate 15

Mourn, and your grief ye Groves in soft sighs breath 5

Muse, first of Arden tell, whose foot-steps yet are found 163

Muses' Elizium, The: 'Description of Elizium' 165

Muses' Elizium, The: Nymphal VI 166

Muses' Elizium, The: Nymphal X 167

My beasts, go fede vpon the plaine 32

My Flocks feede not, my Ewes breede not 108

'My Happy Life, to a Friend' 247

My Lucasia, leave the Mountain tops 273

My sheep are thoughts, which I both guide and serve 48

Nere to a sheapheard did a damsell sit 125

New yeares, expect new gifts: Sister, your Harpe 194

'New-Year's Gift Sung to King Charles, A' 194

'New-Year's Gift to Sir Simeon Steward, A' 245

No newes of Navies burnt at Seas 245

Not Megabotes, nor Cleonymus 98

Now a Botch take thee, Tom: where hast thou beene 215

Now for the last farewell I meane to make 122

Now that the winter's gone, the earth hath lost 233

Now warre is all the world about 217

'Nymph's Reply to the Shepherd, The' 85

O Arethusa, graunt this labour be my last in deede 9

O eies that see not him, who look'd on yow 22

O happie art thou Tityrus 4

O Happie golden Age 33

O how I love these solitudes 203

O Mersa stay, flye not so fast from me 99

O Muses of Sicilia ile let's greater matters sing 8

O Nicias, there is no other remedie for loue 2
O sweet woods the delight of solitarines 50

$\mathrm{O}$ what a Plague is Love 155

O ye Nymphes most fine who resort to this brooke 39

Obsequy of Fair Phillida 152

Ocean to Cynthia, extract 142

'Ode Upon Occasion of His Majesty's Proclamation' 217

Ode IV.21 (Casimir) 231

Oenone and Paris, extract 92

Of all the kindes of common Countrey life 95

Of Gentylnesse and Nobility, extracts 19

'Of Jack and Tom' 212

Of PAN we sing, the best of Singers Pan 193

'Of the Quietness that Plain Country

Bringeth' 54

'Of the Vanity of Wanton Writings' 77

Oh happy, (if his Happiness he knows) 10

Oh! shepherd, oh! shepherd, will you come home 29

'Old Ballet of Shepherd Tom, The' 269

'Old Damon's Pastoral' 78

Old-Fashioned Love, An, Eclogue I 59

On a hill there growes a flower 116

'On Lazy and Sleeping Shepherds' 88

'On the Execrable Murder of Charles I' 277

'On the Reported Death of the Earl of Essex' 129

'On the Rustic Life' 13

'On Westwell Downs' 235

One day as he did raunge the fields abroad 45

One night I did attend my sheepe 90

'Page's Pleasant Rustick, The' 131

'Pan and Syrinx' 61

$P_{A N}$ is our All, by him we breath, wee live 193

Pan's Anniversary, Hymns I, II, III, IIII 193

Paris the Swain, away coy Helen bare 3

Passed contents 23

'Passionate Shepherd to his Love, The' 84

Passionate Shepherd, The, extracts 121, 122

Pastoral Play, Scenes from a 240

'Pastoral Dialogue, A' 260

'Pastoral Dialogue between Coridon and

Thyrsis, A' 250

'Pastoral Elegy on the Death of Sir Antony Alexander, A' 199 
'Pastoral on the King's Death' 272

'Pastoral Riddle, A' 125

'Pastoral Song, A' 264

'Pastoral Song between Phillis and Amarillis, A' 145

'Pastoral Song: with the Answer, A' 263

'Pastoral sung to the King, A' 242

'Pastoral upon the Birth of Prince Charles, A' 241

'Pastorall Wooing, The' 3

Peace sheppheard 123

Perin, arreed what new mischance betide 138

Philisides, the Shepherd good and true 53

'Phillis' 170

Phillida Flouts Me 155

Phylida was a fayer mayde 31

'Phillida's Love-Call to Her Coridon and

His Replying' 133

Phillis Sonnet 481

Phillis Sonnet 1282

Piscatory Eclogue VII (Phineas Fletcher) 219

Plac'd on yon' fair, though beetle brow 266

Pleasant Country Maying Song, A 150

'Pleasant Eclogue between Montanus and Coridon, A' 80

'Pleasure of Retirement, The' 255

Poly-olbion, extracts 163

Poore Harpalus opprest with loue 179

'Poor Shepherd's Introduction, A' 137

'Praise of a Religious Recreation, The' 232

Psalm 23 87, 111

Psyche, extract 249

Purple Island, The, extracts 221

Renowned men their Herds to keep 188

Revelation of the True Minerva, A, extract 55

Rise, Clotten, rise, take up thy Pipe and play 275

'Robene and Makyne' 18

Robene sat on gud grene hill 18

Robin Hood and the Shepherd 156

Say shepheards boy, what makes thee greet so sore? 80

Seelly shepheard Corydon lou'd hartily faire lad Alexis 7
'Second Shepherd's Song, The' 121

Shepheard, ah Shepheard, what sad dayes have we 239

Shepherd and the King, The 153

Shepheard, iffaith now say how wel 101

'Shepherd Inviting a Nymph to His Cottage, A' 171

Shephard loueth thow me vell? 36

Shepheard why creepe we in this lowly vaine 161

'Shepherds, The' 251

Sheapheards be sylent, and our musick cease 137

Shepherd's Calender, The, 'April' 38

Shepherd's Calender, The, 'July' 41

Shepherd's Calender, The, 'June' 40

Shepherd's Complaint, The, extracts 105, 106

Shepherd's Content, The 1-14, 140-237, 273-9396

'Shepherd's Dialogue of Love, The' 205

'Shepherd's Dream, A' 119

'Shepherd's Employment Is Too Mean an Allegory for Noble Ladies, A' 257

'Shepherds' Holiday, The' (Brathwait) 207

Shepherd's Holiday, The, extract (Denny) 253

Shepherd's Hunting, The, Ecl.V 185

Shepherd's Lamentation, The 148

'Shepherd's Ode, The' 71

Shepherd's Oracle, The 239

'Shepherd's Sirena, The' 164

'Shepherds' Song for Christmas' 135

'Shepherds' Spring Song, The' 146

Shepherds' Tales, extracts 206, 207, 208

Shepheards that wont on pipes of oaten reed 43

'Shepherd's Wife's Song, The' 75

'Shepherdess Her Reply, The' 127

Should Cronicles wherein thy founders name 237

Siluan Muses can yee sing 121

'Similizing the Sea to Meadows and Pastures' 258

Since first thy soile O countrie Pan I knewe 63

Since that to death is gone the shepheard hie 52

Sing his praises that doth keep 175

Sing sing (Parthenophil) sing, pipe, and play 91 
Sing vs that carroll (Damian) 83

Sing you, plaie you; but sing and play my truth 66

Sirinx, one of Dian's traine 94

Sit down Carmela here are cubbs for kings 73

'Solitude, The' 203

'Song' (Passerat) 36

'Song' (Wroth) 209

'Song, A' ('As Colin went forth') 265

'Song in praise of Eliza, A' 63

'Song of a Country Swain at the Return of Philador, The' 76

'Sonet, A' (William Herbert) 216

'Sonnet, A' (D’Urfé) 176

'Spring, The' 233

Strangwaies leaue London and her sweet contents 109

Sundry Christian Passions, Part I Sonnet 9110

Sweet, harmles lives! (on whose holy leisure 251

Sweete Musique, sweeter farre 135

Sweete Phillis, if a silly Swaine 120

Sweet Phillis Venus sweetyng was, was none so swete as she 60

Sweet shepperdisse 126

'Tale of Robin Hood, A' 62

Taylor's Pastoral, extracts 213

'Technis' Tale' 206

Tell me good Hobbinoll, what garres thee greete? 38

Tell me Loue what thou canst doe? 208

'That a pleasant poverty is to bee preferred before discontented riches' 224

The Brutons thus departed hence, Seauen Kingdomes here begonne 56

The early Morn lets out the peeping day 221

The fairest nymph that vallyes 152

The famous Poetes with the Muses nine 25

The fieldes are grene, the springe growes on a pace 118

The golden god Hyperion 149

The innocence, truth, and simplicitie 93

The life of a Shepherd is void of all care-a 270

The Lord my Sheaperd is, hee doth mee feed 87
The lord he is my sheepheard, that doth feede 111

The Loue Alexis did to Damon beare 198

The Shepheard Colliden, who ere him know 169

The shepheard good doth watch his sheepe 88

The shepherds guarded from the sparkling heat 221

The Shepherdesses which great Flocks doe keep 256

The shepheards boy (best knowne by that name) 42

The shepherds sing; and shall I silent be? 222

The silent shade had shadowed euery tree 76

The Sunne that had himselfe a Courtier beene 168

The Sunne the season in each thing 136

The sweatie sith-man with his rasor keene $2 \mathrm{O} 2$

The warmer Sun the golden Bull outran 221

The Waves like Ridges of Plow'd-land lies high 258

Then Pan (when Neptune had Apollos place) 55

Thenot and Chloris, red lipt Driope 146

Thenot my deare, how can a lofty hill 220

'Thenot's Abode' 236

Theophila's Love Sacrifice, extract 255

'Theorello the Shepherd's Idillion' 132

There are no suerties (good friend) will be taken 174

There on a day as he pursew'd the chace 44 There was a Shepheards Daughter 158

There where the pleasant Eske 37

This great difference and first diuersitie 16

This is the Seate of sweet Repose for Swaines 253

Thou art not, Penshvrst, built to enuious show 191

Though Amarillis daunce in greene 70

Though frost, and snow, lockt from mine eyes 234

Though Tytirus the Heards swaine 77

Thrice famous Saxon King, on whom Time nere shall pray 163

Through the shrubs as I can crack 72 
Thus spend we time in laughter 218

Tityrus, happilie thou lyste tumbling vnder a beech tree 6

'To Amarillis' 70

To cover Noble Lovers in Shepherds weeds 257

'To his Little Field' 20

'To his Loving Friend Master John Fletcher' 174

'To His Much Loved Friend Master W. Browne' 183

'To His Muse' 243

'To My Beloved Thenot in Answer of His Verse' 220

'To my Ingenious Friend Master Brome' 271

'To My Noblest Friend, I.C. Esquire' 223

'To Penshurst' 191

'To Reverend Colin' 83

'To Saxham' 234

'To Sir Robert Wroth' 192

'To Thomas Strangways' 109

Tom and Will 238

Tom and Will were Shepherds Swains 238

T'was yerst (my sweet) I on my oaten reede 277

Two nights thus past: the Lilly-handed Morne 189

Two prettie Rills doe meet, and meeting make 186

Vnder this Beech why sit'st thou here so sad 226

'Unknown Shepherd's Complaint, The' 108

Vnworthy, though, ô LORD, we are 187

Vpon a deintie hill sumtime 112

'Upon a Kiss Given' 126

'Upon Cloris Her Visit after Marriage' 262

Vppon the hilles of Arcadie 131

Vpon the smooth Arcadian plain 157

'Votum Primum' 130

Walkeing betimes close by a green wood side 267

Walking in a valley greene 71

We that have knowne no greater state 93

Watt boy whether now so faste? 62

What, breathles Nimphs? bright Virgins let me know 167

What Clod-pates Thenot are our Brittish swaines? 228

What clouds, Menalcas, do oppress thy brow? 252

What pleasure haue great princes 69

Whatt suddaine Chaunce hath darkt of late 212

What think'st O Galbula, that where of yore 17

When by the pleasant streams of Thames poore caitif Amintas 57

When I was a little swain 124

When Ioue first broken had the Chaos ancient 100

When Westwell downes I gan to treade 235

Where England's Damon us'd to keep 272

Wherefore if you loue me 176

Whil'st in the open Field our Watch we kep'd 249

Whither Mad maiden wilt thou roame? 243

Who Chance, Change, Hopes, and Fears can under bring 255

Who so Enjoyes the Cuntry Ayer 248

Why (Damon) did Arcadian Pan ordain 262

Why ô doth gaudy Tagus ravish thee 224

Why sigh you swain? this passion is not common 229

Why Strephon, art thou melancholy grown 268

Willy well met, now whiles thy flockes do feed 183

WILLY, why lig'st thou (man) so wo-begon? 184

With louely Netehearde Daphnis on the hills, they saie 1

'Wodenfride's Song in Praise of Amargana' 136

Wood-men Shepherds, come away 214

Yet once more, $\mathrm{O}$ ye laurels, and once more 230

You Fawnes and Siluans, when my Chloris brings 104

You Gote-heard Gods, that loue the grassie mountaines 51

You pleasant flowrie mead 211

You Sheepheards which on hillocks sit 132 